\title{
Effect of platelet-activating factor on the electrophysiology of the human Fallopian tube: early mediation of embryo-maternal dialogue?
}

\author{
S. J. Downing ${ }^{1}$, S. D. Maguiness ${ }^{2}$, J. I. Tay ${ }^{3}$, \\ A. Watson ${ }^{2}$ and H. J. Leese ${ }^{1}$ \\ ${ }^{1}$ Department of Biology, University of York, PO Box 373, York YO21 5YW, UK; \\ ${ }^{2}$ The Princess Royal Hospital, Saltshouse Road, Hull HU8 9HE, UK; and ${ }^{3}$ Department \\ of Obstetrics and Gynaecology, D Floor, Clarendon Wing, Leeds General Infirmary, \\ Belmont Grove, Leeds LS2 9NS, UK
}

\begin{abstract}
Platelet-activating factor (PAF) is produced by preimplantation embryos and may be involved in the earliest stages of embryo-maternal dialogue. This study explored the potential effects of PAF acting as a signalling agent on human Fallopian tubal epithelial cells grown as a polarized layer in primary culture. The response of the tubal epithelium was assessed in terms of the transepithelial potential difference and short-circuit current $\left(I_{\text {scc }}\right)$, which were recorded using a modified Ussing chamber. Resistance was calculated from the measurements of potential difference and $I_{\text {scc }}$. PAF (1.9 nmol to $\left.1.9 \mu \mathrm{mol} \mathrm{I}^{-1}\right)$ administered to the apical surface of the cells produced a marked, transient increase in both potential difference and $I_{\text {scc }}$ in a dose-
\end{abstract}

\section{Introduction}

The Fallopian tube is the site of ovum and sperm transport, fertilization and early embryo development. Tubal fluid, secreted by the epithelial cells lining the inner surface of the oviduct, provides the optimum environment for these processes, but the mechanism and regulation of its secretion are poorly understood (Leese et al., 2001). The rate of secretion and composition of tubal fluid may vary to satisfy the different temporal requirements of the gametes and embryo. It is also possible that the gametes and embryos release signals that influence the function of tubal epithelial cells. For example, Ortiz et al. (1986) observed that hamster embryos were transported to the uterus faster than unfertilized oocytes indicating a role for local signals. One such candidate as a gamete/embryo-maternal signal is plateletactivating factor (PAF), which is produced by spermatozoa (Roudebush and Purnell, 2000) and by preimplantation embryos of mice (O' Neill, 1985), hamsters (Velasquez et al., 1995) and cattle (Hansel et al., 1989). Receptors for PAF are located in the endosalpinx of hamsters and mice (Stoddart et al., 1996; Velasquez et al., 1997, 2001; Lash and Legge, 2001). PAF has also been shown to increase

Email: sjd13@york.ac.uk dependent manner. The mode of action of PAF on the electrophysiological responses of human tubal epithelial cells was investigated. Blockers of $\mathrm{Na}^{+}, \mathrm{K}^{+}$and voltageoperated $\mathrm{Ca}^{2+}$ channels had little effect on PAF action. However, incubation of the epithelial cells in $\mathrm{Cl}^{-}$-free medium or with a blocker of the $\mathrm{Na}^{+}-\mathrm{K}^{+}-2 \mathrm{Cl}^{-}$cotransporter (Furosemide) reduced the effect of PAF. Blockade of chloride-bicarbonate channels with 4 -acetamido-4'-isothiocyanostilbene-2.2'-disulphonic acid (SITS) reduced the effect of low doses of PAF only. These results indicate that PAF influences the movement of chloride ions across the tubal epithelial cell and is a candidate molecule for initial embryo-maternal dialogue. intracellular $\mathrm{Ca}^{2+}$ concentrations in cultured bovine oviduct endosalpingeal cells (Tiemann et al., 1996) via influx of extracellular $\mathrm{Ca}^{2+}$. In other tissues, PAF action is mediated by prostaglandins (for a review, see Chao and Olson, 1993).

Fluid movements across epithelia are secondary to the movement of solutes, particularly ions. Such movement of ions results in an asymmetrical distribution of ionic charge and thus generates a transepithelial electrical potential difference that can be measured experimentally. Furthermore, the passage of ions across epithelia can be modulated using selective blockers of ion channels. Gott et al. (1988) and Dickens and Leese (1994) used a vascular perfusion technique to demonstrate that basal to apical movements of chloride ions were associated with tubal fluid secretion in the rabbit oviduct. These $\mathrm{Cl}^{-}$fluxes were sensitive to blockade of $\mathrm{Cl}^{-}-\mathrm{HCO}_{3}{ }^{-}$exchange and $\mathrm{Na}^{+}-\mathrm{K}^{+}-\mathrm{Cl}^{-}$cotransport (Gott et al., 1988). This finding is consistent with the oviduct having a $\mathrm{Cl}^{-}$secretory epithelium, as is also found in other tissues, such as the kidney proximal tubule and the airways (O'Grady et al., 1987; Case et al., 1989; Quinton, 1990). Rabbit and human oviduct epithelial cells, grown as a polarized layer in primary culture, also demonstrated greater chloride ion flux in the secretory (basal to apical) direction than in the absorptive (apical to basal) direction (Dickens et al., 1993, 1996). In other studies it has been 
shown that the movement of chloride ions is a major factor in the generation of the transepithelial potential difference across cultured human Fallopian tubal epithelial cells and that agonists, such as extracellular ATP or PAF, are potent modulators of electrophysiological activity (Downing et al., 1997, 1999; Reischl et al., 1999, 2000). Downing et al. (1999) demonstrated that PAF has a greater effect on transepithelial potential difference and $I_{\text {SCC }}$ when it is applied to the apical surface of the tubal epithelial cells rather than to the basal surface; this finding is consistent with a putative role as a gamete/embryo-maternal signalling molecule.

The present study examined the effect of blockers of $\mathrm{Na}^{+}$, $\mathrm{K}^{+}$, voltage operated $\mathrm{Ca}^{2+}$ and $\mathrm{Cl}^{-}$channels on PAF-induced electrophysiological responses of primary cultures of human Fallopian tubal epithelial cells.

\section{Materials and Methods}

Human Fallopian tubes, at various stages of the menstrual cycle, were removed from pre-menopausal patients attending for hysterectomy at the Princess Royal Hospital (Hull). Permission was granted by the Hull and East Yorkshire Ethics and Clinical Trials Committee, and informed consent was always obtained from patients.

Fallopian tubes were donated by 27 women whose mean age was $40.3 \pm 1.2$ years (range $25-52$ years). The patients were undergoing hysterectomy for menorrhagia, dysmenorrhoea, fibroids or sterilization. None of the patients had taken oral contraceptives or received other hormonal medication. Tubal disease had not been diagnosed. From the date of the last menstrual period, as given by the patient, Fallopian tubes were obtained from five patients who were in the follicular phase (days 1-14), ten patients who were in the luteal phase (days 15-28), two patients who were menstruating at the time of surgery and five patients who had not experienced menstruation for $>60$ days (menopausal); the date of the last menstrual period was not available for four patients.

\section{Epithelial cell culture}

Epithelial cells were isolated according to the method of Dickens et al. (1993), which is a modification of methods devised by Glasser et al. (1988) and Kimber et al. (1993). Immediately after removal from the patient, the Fallopian tubes were washed in Hank's balanced salt solution without $\mathrm{Ca}^{2+}$ or $\mathrm{Mg}^{2+}\left(\mathrm{Ca}^{2+}-\mathrm{Mg}^{2+}\right.$-free HBSS, Gibco, Life Technologies Ltd, Paisley) and connective tissue was removed. The tubes were opened longitudinally, cut into $1 \mathrm{~cm}$ pieces and incubated in $\mathrm{Ca}^{2+}-\mathrm{Mg}^{2+}$-free HBSS containing $0.5 \%(\mathrm{w} / \mathrm{v})$ type I trypsin (Sigma Chemical Co, Poole) and 2.7\% (w/v) pancreatin (Gibco) for $1 \mathrm{~h}$ at $4^{\circ} \mathrm{C}$. This procedure was followed by further incubation for $1 \mathrm{~h}$ at room temperature. The enzyme medium was removed, $\mathrm{Ca}^{2+}-\mathrm{Mg}^{2+}$-free HBSS added and the epithelial cells vortexed into suspension. After centrifugation at $250 \mathrm{~g}$ for $5 \mathrm{~min}$, the cells were washed in $\mathrm{Ca}^{2+}-\mathrm{Mg}^{2+}$-free $\mathrm{HBSS}$ and centrifuged again three times. After washing, cells were resuspended in prewarmed, pre-gassed culture medium at a density of $1 \times 10^{6}$ cells $\mathrm{ml}^{-1}$. Cell viability, as tested by the ability to exclude trypan blue $(0.4 \%$, w/v), was $>95 \%$. Culture medium consisted of nutrient mixture F12 (Sigma) plus Dulbecco's modified Eagle's medium (DMEM) (1:1, v/v) (Sigma) containing $0.1 \%(\mathrm{w} / \mathrm{v})$ BSA (ICN-Flow, Oxfordshire), $270.0 \mathrm{U}$ penicillin $\mathrm{ml}^{-1}, 270.0 \mu \mathrm{g}$ streptomycin $\mathrm{ml}^{-1}$ (Sigma), $20.0 \mu \mathrm{g}$ fungizone $\mathrm{ml}^{-1}$ (Gibco), $2.5 \mathrm{mmol}$ glutamine $\mathrm{I}^{-1}$ (Sigma), 2.5\% (v/v) Nu-serum (ICN-Flow) and $2.5 \%(\mathrm{v} / \mathrm{v})$ heat-inactivated fetal calf serum (Gibco). The cell suspension $(250 \mu \mathrm{l})$ was placed in the top of Snapwell filters, $1.0 \mathrm{~cm}^{2}, \quad 0.4 \mu \mathrm{m}$ pore size (Corning Costar Corporation, Cambridge, MA) coated with Pronectin F (Protein Polymer Technologies, Inc, San Diego, CA) in multiwell plates, and fresh medium was added under the filters. The cells were incubated in a humidified incubator at $37^{\circ} \mathrm{C}$ in $5 \% \mathrm{CO}_{2}$ in air. The medium above and below the filters was replaced every $48 \mathrm{~h}$ until the cells became confluent. Fallopian tubes from one patient usually yielded sufficient cells for 6-10 filters.

When the cells became confluent, the filters were placed in modified Ussing chambers (World Precision Instruments Inc, Sarasota, FL), and both surfaces of the cells were bathed with normal Krebs'-Ringer bicarbonate solution in 95\% $\mathrm{O}_{2}$ and $5 \% \mathrm{CO}_{2}$ at $37.5^{\circ} \mathrm{C}$. The cells were alternately clamped at $0 \mathrm{mV}$ for $5 \mathrm{~s}$ and $+5 \mu \mathrm{A}$ for $1 \mathrm{~s}$ using pairs of glass $\mathrm{KCl}$ electrodes. This procedure permitted almost simultaneous recording of short-circuit current $\left(I_{\mathrm{SCC}}\right)$ and potential difference. Resistance $(R)$ was calculated from the measurements of potential difference and $I_{\text {scc }}$. The normal Krebs'-Ringer bicarbonate solution contained: $118.0 \mathrm{mmol}$ $\mathrm{NaCl} \mathrm{I-1}, 25.0 \mathrm{mmol} \mathrm{NaHCO}_{3}{ }^{-1}, 4.74 \mathrm{mmol} \mathrm{KCl} \mathrm{I-1}$, $1.19 \mathrm{mmol} \mathrm{MgSO}_{4} \mathrm{I}^{-1}, 1.17 \mathrm{mmol} \mathrm{KH}_{2} \mathrm{PO}_{4} \mathrm{I}^{-1}, 1.17 \mathrm{mmol}$ $\mathrm{CaCl}_{2} \mathrm{I}^{-1}, 5.5 \mathrm{mmol}_{\text {glucose }} \mathrm{I}^{-1}$ gassed with $95 \% \mathrm{O}_{2}$ and $5 \%$ $\mathrm{CO}_{2}$. In the $\mathrm{Cl}^{-}$-free medium, $\mathrm{NaCl}, \mathrm{KCl}$ and $\mathrm{CaCl}_{2}$ were replaced with sodium gluconate, potassium gluconate and calcium gluconate, respectively. Ion channel blocking agents were made up in normal Krebs'-Ringer (tetraethylammonium chloride (TEA)), methanol (verapamil) or DMSO (furosemide, amiloride) and $10 \mu \mathrm{l}$ of stock solution was added to the bathing medium to achieve the appropriate final concentrations. SITS was made up in normal Krebs'Ringer bicarbonate and $400 \mu$ l of the stock solution was added to produce the required final concentration in the bathing medium. PAF was made up in normal Krebs'Ringer bicarbonate or $\mathrm{Cl}^{-}$-free medium and added in $40 \mu \mathrm{l}$ volumes to the apical bathing medium. The cells were washed in fresh Krebs'-Ringer bicarbonate and application of the same agonist was repeated after 20 mins, to prevent desensitization of the cells to agonists. When ion channel blocking agents were used, the cells were incubated in the presence of the blocker for 20 min before addition of PAF.

Where possible, one filter from the tubes of each patient was used as a control and a separate filter was used for each ion channel blocker/Cl--free medium treatment group. Only one filter from each patient was allocated to each 
Table 1. Resting values for potential difference $(P D)$, short-circuit current $\left(I_{\mathrm{scC}}\right)$ and resistance $(R)$ in cultured human Fallopian tubal epithelial cells

\begin{tabular}{lcccc}
\hline $\begin{array}{l}\text { Day of menstrual } \\
\text { cycle }\end{array}$ & $\begin{array}{c}\text { Number of } \\
\text { patients }\end{array}$ & $P D(\mathrm{mV})$ & $I_{\mathrm{scc}}(\mu \mathrm{A})$ & $R\left(\Omega \mathrm{cm}^{-2}\right)$ \\
\hline Days 1-14 & 5 & $5.4 \pm 0.6$ & $-28.7 \pm 4.2$ & $196.6 \pm 18.9$ \\
Days 15-28 & 10 & $3.5 \pm 0.3$ & $-20.7 \pm 2.3$ & $178.8 \pm 13.6$ \\
Menstruating & 2 & 5.2 & -18.3 & 287.4 \\
Menopausal & 5 & $3.6 \pm 0.8$ & $-18.4 \pm 1.7$ & $195.0 \pm 25.4$ \\
\hline
\end{tabular}

Values are mean \pm SEM.

Table 2. Change in potential difference $(P D)$ and short-circuit current $\left(I_{\mathrm{scC}}\right)$ in response to plateletactivating factor (PAF) in cultured human Fallopian tubal epithelial cells

\begin{tabular}{ccccc}
\hline & & \multicolumn{3}{c}{ Day of menstrual cycle } \\
\cline { 3 - 5 } $\begin{array}{l}\text { PAF } \\
\left(\mathrm{nmol}{ }^{-1}\right)\end{array}$ & Parameter & $\begin{array}{c}\text { Days } 1-14 \\
(n=4)\end{array}$ & $\begin{array}{c}\text { Days } 15-28 \\
(n=4)\end{array}$ & $\begin{array}{c}\text { Other* } \\
(n=6)\end{array}$ \\
\hline \multirow{2}{*}{1.9} & $P D(\mathrm{mV})$ & $1.0 \pm 0.8$ & $0.5 \pm 0.3$ & $0.4 \pm 0.2$ \\
& $I_{\mathrm{scc}}(\mu \mathrm{A})$ & $5.4 \pm 2.0$ & $3.3 \pm 2.0$ & $1.2 \pm 1.3$ \\
19.0 & $P D(\mathrm{mV})$ & $0.6 \pm 0.5$ & $0.7 \pm 0.3$ & $1.0 \pm 0.3$ \\
190.0 & $I_{\mathrm{scc}}(\mu \mathrm{A})$ & $3.7 \pm 3.2$ & $5.3 \pm 1.6$ & $5.5 \pm 1.6$ \\
& $P D(\mathrm{mV})$ & $1.0 \pm 0.4$ & $1.4 \pm 0.2$ & $7.3 \pm 0.2$ \\
1900.0 & $I_{\mathrm{scc}}(\mu \mathrm{A})$ & $7.8 \pm 6.1$ & $10.9 \pm 3.2$ & $2.2 \pm 0.5$ \\
& $P D(\mathrm{mV})$ & $1.4 \pm 0.3$ & $1.9 \pm 0.1$ & $15.8 \pm 4.7$ \\
\hline
\end{tabular}

Values are mean \pm SEM.

*Other filters comprise menstruating $(n=2)$, menopausal $(n=2)$ and unknown day of menstrual cycle $(n=2)$.

treatment group. Each filter was used for one treatment only.

Amiloride, TEA, SITS, furosemide, verapamil and PAF were obtained from Sigma. Doses of ion channel blockers used in the present study were similar to those used in studies on airway, endometrial, kidney and other cultured epithelia (Gott et al., 1988; Hanglow et al., 1989; Zeitlin et al., 1989; MacNaughton and Gall, 1991; Matthews et al., 1993; Dickens and Leese, 1994; Jin and Hopfer, 1997; Deachapunya and O'Grady 1998) and were appropriate to produce selective blockade of the ion channel under investigation.

Results were analysed by Kruskal-Wallis test followed by Mann-Whitney U test (Dytham, 1999).

\section{Results}

Epithelial cells from human Fallopian tubes formed a polarized layer, which became confluent usually at days 5-6 of culture. The cells formed a rather leaky electrical system; mean values for resting potential difference, shortcircuit current and resistance were $3.3 \pm 0.2 \mathrm{mV}$, $-22.3 \pm 1.6 \mu \mathrm{A}$ and $165.8 \pm 6.3 \Omega \mathrm{cm}^{-2}$, respectively ( $n=95$ filters). The filters were used only if values for resistance of at least $100 \Omega \mathrm{cm}^{-2}$ could be achieved. No difference in resting values was observed for tubes taken at various stages of the menstrual cycle (Table 1 ).

\section{Effects of PAF on transepithelial potential difference and $I_{S C C}$}

Our previous study showed that PAF had a greater effect on potential difference and $I_{\text {scc }}$ when applied to the apical surface of the epithelial cells rather than to the basal surface (Fig. 1). As in the previous study, PAF $\left(1.9 \mathrm{nmol} \mathrm{I}^{-1}\right.$ to $1.9 \mu \mathrm{mol} \mathrm{I}^{-1}, n=14$ filters) applied to the apical surface of the cells produced an increase in potential difference and $I_{\text {scc }}$ in a dose-dependent manner (Fig. 2). There was no difference in response to PAF in epithelial cells taken from Fallopian tubes removed at different stages of the menstrual cycle (Table 2).

\section{Effect of ion channel blockers on PAF action}

Preincubation of the cultured epithelial cells for 20 min in $\mathrm{Cl}^{-}$-free medium significantly reduced the PAF-induced increase in potential difference and $I_{\mathrm{scc}}$ at all doses of PAF (Fig. 2) (potential difference: $P<0.003$ at $1.9 \mathrm{nmol} \mathrm{PAF} \mathrm{I-1}^{-1}$, $P<0.0004$ at $1.9 \mu \mathrm{mol}$ PAF I-1; $I_{\text {scc }}: P<0.01$ at $1.9 \mathrm{nmol}$

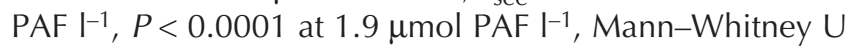
test) compared with untreated controls. Similarly, furosemide $\left(100 \mu \mathrm{mol} \mathrm{I}{ }^{-1}\right)$, which blocks $\mathrm{Na}^{+}-\mathrm{K}^{+}-2 \mathrm{Cl}^{-}$cotransport, reduced the effect of PAF on potential difference $\left(P<0.02\right.$ at $1.9 \mathrm{nmol} \mathrm{PAF} \mathrm{I}^{-1}, P<0.01$ at $19.0 \mathrm{nmol} \mathrm{PAF} \mathrm{I}^{-1}$ and $P<0.02$ at $1.9 \mu \mathrm{mol}$ PAF $\left.\right|^{-1}$ ) compared with the controls. $I_{\text {scC }}$ response to PAF was reduced significantly at 19 nmol PAF I-1 only $(P<0.05)$. SITS $\left(1 \mathrm{mmol} \mathrm{I}^{-1}\right)$, which 


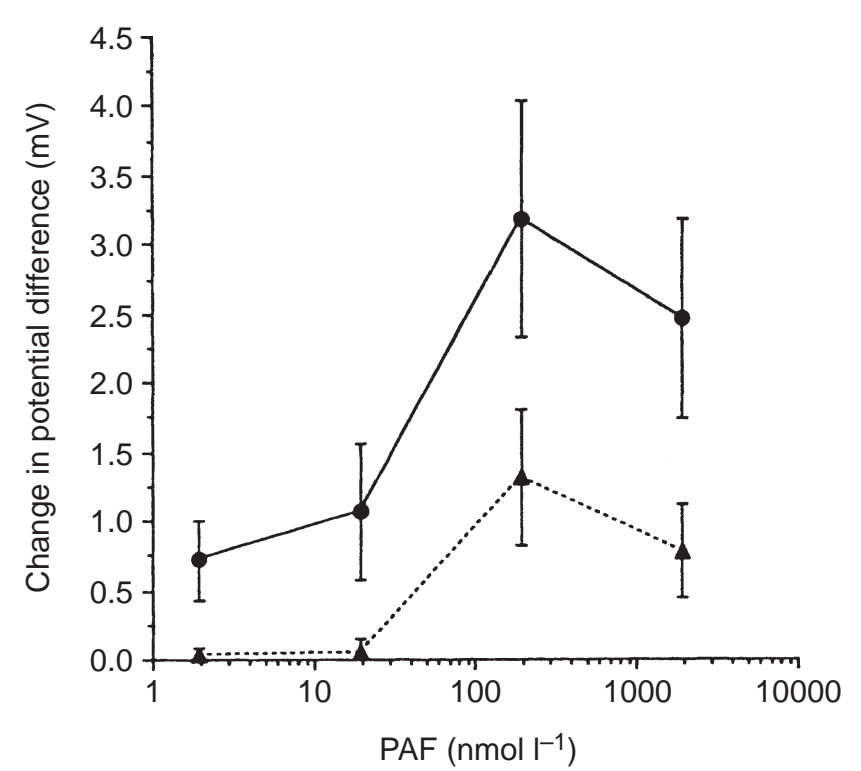

Fig. 1. Change in transepithelial potential difference in cultured human oviductal cells with increasing concentration of plateletactivating factor (PAF) applied to either the apical $(\bullet, n=8)$ or the basal surface $(\boldsymbol{\Lambda}, n=7)$ of the cells. Values are mean \pm SEM. (Reproduced from Biology of Reproduction (1999) 61 657-664 with kind permission from the Society for the Study of Reproduction).

blocks chloride-bicarbonate channels, reduced the PAFstimulated increase in potential difference and $I_{\text {scC }}$ at low doses of PAF (potential difference: $P<0.05$ at $1.9 \mathrm{nmol}$ PAF $\mathrm{I}^{-1} ; \quad P<0.02$ at $19 \mathrm{nmol}$ PAF $\mathrm{I}^{-1}$ ) only, compared with controls. Preincubation with amiloride $\left(10 \mu \mathrm{mol} \mathrm{I}{ }^{-1}, \mathrm{Na}^{+}\right.$ channel blocker), TEA (25 mmol $\mathrm{I}^{-1}, \mathrm{~K}^{+}$channel blocker) or verapamil $\left(100 \mu \mathrm{mol} \mathrm{I}{ }^{-1}\right.$, voltage-operated $\mathrm{Ca}^{2+}$ channel blocker) had little effect on PAF-induced increases in potential difference and $I_{\mathrm{scc}}$. The vehicles used to prepare solutions of the ion-blocking agents had no significant effect on the response of the epithelial cells to PAF (Fig. 3).

\section{Discussion}

Modulation of transepithelial permeability of ions occurs via alteration in the permeability of the tight junctions between cells or in the permeability of the apical and/or the basolateral membranes of the epithelial cells, resulting in a change in the rate or direction of movement of ions (Lewis et al., 1995). Thus, agonists that alter ion permeability or movement across a secretory epithelium will influence the rate of fluid formation and secretion. Therefore, it is likely that PAF, which exerts its effects on tubal epithelial cell electrophysiology, modulates fluid formation and secretion in the human Fallopian tube. The present study has shown that the response of cultured human Fallopian tubal epithelial cells to apically applied PAF occurs primarily via changes in transepithelial flux of chloride ions. In secretory epithelia, chloride ion movements from the basal to apical poles of the cells play a significant role in providing the driving force for the movement of fluid (O'Grady et al., 1987; Case et al., 1989; Quinton, 1990). Furosemide, which inhibits the $\mathrm{Na}^{+}-\mathrm{K}^{+}-2 \mathrm{Cl}^{-}$cotransporter was effective at inhibiting PAF-induced increases in potential difference and $I_{\mathrm{scc}}$ in tubal epithelial cells in the present study. SITS, which blocks the $\mathrm{Cl}^{-}-\mathrm{HCO}_{3}{ }^{-}$antiporter, inhibited PAF action only at low concentrations of PAF (1.9-19.0 nmol PAF $\left.{ }^{-1}\right)$. At higher concentrations of PAF, activation of the $\mathrm{Na}^{+}-\mathrm{K}^{+}-2 \mathrm{Cl}^{-}$cotransporter may be sufficient to increase potential difference and, therefore, chloride ion movement, despite continued blockade of the $\mathrm{Cl}^{-}-\mathrm{HCO}_{3}{ }^{-}$antiporter. Verapamil was ineffective at inhibiting PAF-stimulated increases in potential difference and $I_{\mathrm{SCC}}$ indicating that inward movement of $\mathrm{Ca}^{2+}$ is not required for initiation of $\mathrm{Cl}^{-}$ fluxes. It is possible that release of $\mathrm{Ca}^{2+}$ from intracellular stores is sufficient to ensure chloride ion movements.

The response of the cultured epithelial cells to PAF did not appear to be influenced by the stage of the menstrual cycle at the time of removal of the Fallopian tubes from the patient. However, it is likely that any influence of ovarian hormones may have diminished during culture of the epithelial cells. It is known that morphological features, such as cilia, are lost during culture (Bongso et al., 1989; Henriksen et al., 1990), although functional polarity is retained. Culture of the cells in the presence of oestrogen either prevents loss of cilia or induces their regrowth (Comer et al., 1998).

Previous work from this laboratory has shown that, using this isolation method, primary cultures consist of cells that are epithelial in nature (Dickens et al., 1996). Immunostaining showed the presence of secretory, basal and ciliated cells, with little or no contamination by stromal cells (Comer et al., 1998). It would be expected that stromal cell contamination would prevent the formation of tight junctions between all cells, resulting in filters with low potential difference and resistance, which would not be used for experimentation. It is also likely that the different types of epithelial cell have different sensitivities to PAF and may be influenced to different extents by ovarian steroid hormones. It is not known whether the isolation procedure adversely affects the sensitivity of the cells, or the ion channels to PAF.

Tissue concentrations of PAF are governed by the equilibrium between biosynthesis and degradation by PAF-acetylhydrolase (Matsubara et al., 1997). Uterine concentrations of PAF in the rabbit reach a peak of about 38 pmol g-1 during early pregnancy (Angle et al., 1988). In the human uterus, PAF concentrations are low, but are increased by progesterone and oestrogen (Alecozay et al., 1989; 1991). Oviductal concentrations of PAF have not been determined; however, it is generally accepted that cells must be stimulated to produce PAF (Kasamo et al., 1992). In other tissues, cells respond to PAF by producing more PAF in a positive feedback loop (Chao and Olson, 1993); thus local concentrations could be higher.

PAF is secreted by human spermatozoa. It is also secreted by the early developing embryos in hamsters (Velasquez 
(a)

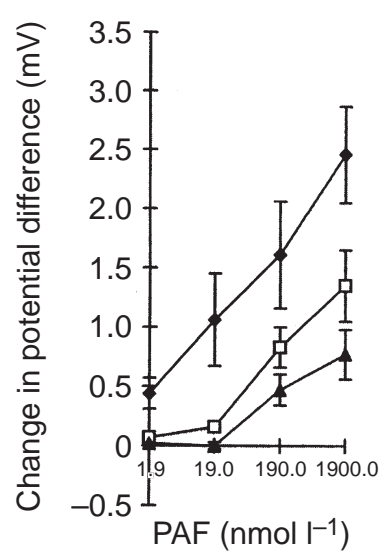

(d)

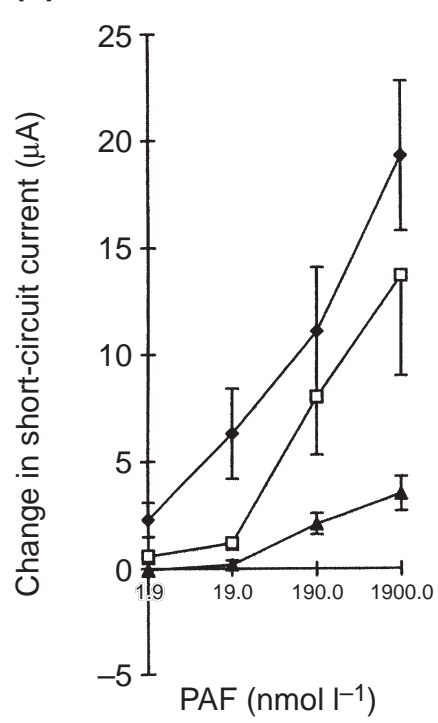

(b)

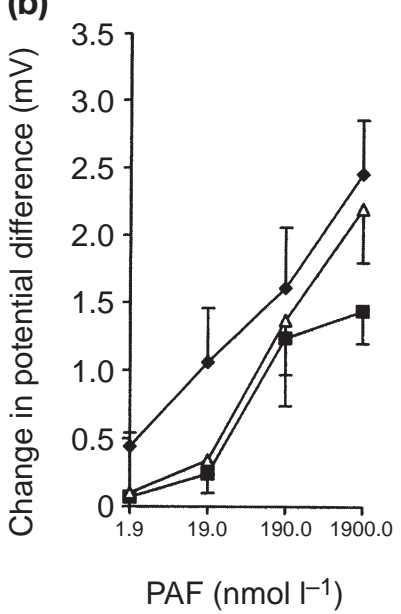

(e) 25

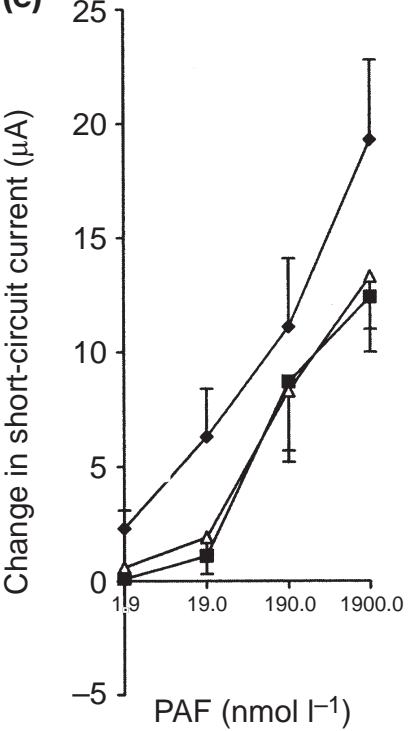

(c)

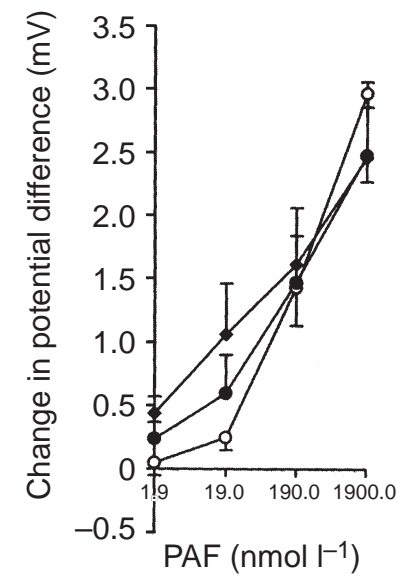

(f)

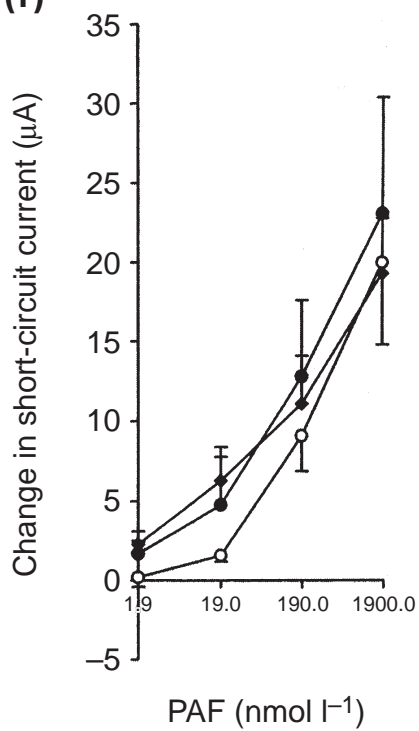

Fig. 2. (a) Change in potential difference with increasing concentration of platelet-activating factor (PAF) in cultured human Fallopian tubal epithelial cells in the absence $(\bullet, n=14)$ or presence of $100 \mu \mathrm{mol}$ furosemide $\mathrm{I}^{-1}(\square, n=10)$ or chloride-free medium $(\boldsymbol{\Lambda}, n=11)$. (b) Change in potential difference with increasing concentration of PAF in cultured human Fallopian tubal epithelial cells in the absence $(\bullet, n=14)$ or presence of $1 \mathrm{mmol} 4$-acetamido-4'-isothiocyanostilbene-2.2' -disulphonic acid (SITS) $\mathrm{I}^{-1}(\mathbf{\square}, n=10)$ or $100 \mu \mathrm{mol}$ verapamil $\mathrm{I}^{-1}(\triangle, n=10)$. (c) Change in potential difference with increasing concentration of PAF in cultured human Fallopian tubal epithelial cells in the absence $(\bullet, n=14)$ or presence of 25 mmol tetraethylammonium chloride (TEA) $\mathrm{I}^{-1}(\mathrm{O}, n=10)$ or $10 \mu \mathrm{mol}$ amiloride $\mathrm{I}^{-1}(\mathbf{O}, n=10)$. (d) Change in short-circuit current with increasing concentration of PAF in cultured human tubal epithelial cells in the absence $(\forall, n=14)$ or presence of $100 \mu$ mol furosemide $\mathrm{I}^{-1}(\square, n=10)$ or chloride-free medium $(\boldsymbol{\Lambda}, n=11)$. (e) Change in short-circuit current with increasing concentration of PAF in cultured human Fallopian tubal epithelial cells in the absence $(\bullet, n=14)$ or presence of $1 \mathrm{mmol} \mathrm{SITS} \mathrm{I}^{-1}(\mathbf{\square}, n=10)$ or $100 \mu \mathrm{mol}$ verapamil $\mathrm{I}^{-1}(\triangle, n=10)$. (f) Change in shortcircuit current with increasing concentration of PAF in cultured human Fallopian tubal epithelial cells

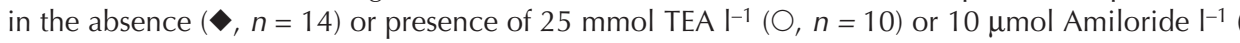
$n=10)$. Values represent Fallopian mean \pm SEM.

et al., 1995), cows (Hansel et al., 1989) and mice (O'Neill, 1985). Rabbit embryos secrete PAF from the two-cell stage, producing nearly $40 \mathrm{ng}$ PAF per embryo per $24 \mathrm{~h}$ on day 4 (Minhas et al., 1993). Administration of PAF hastened the passage of oocytes to the uterus (Velasquez et al., 1995), whereas administration of PAF antagonists retarded the passage of embryos to the uterus. In the mouse, embryoderived PAF promotes further embryonic development in vitro (Stoddart et al., 1996) by a paracrine mechanism. Receptors for PAF have been found in oviduct epithelial 

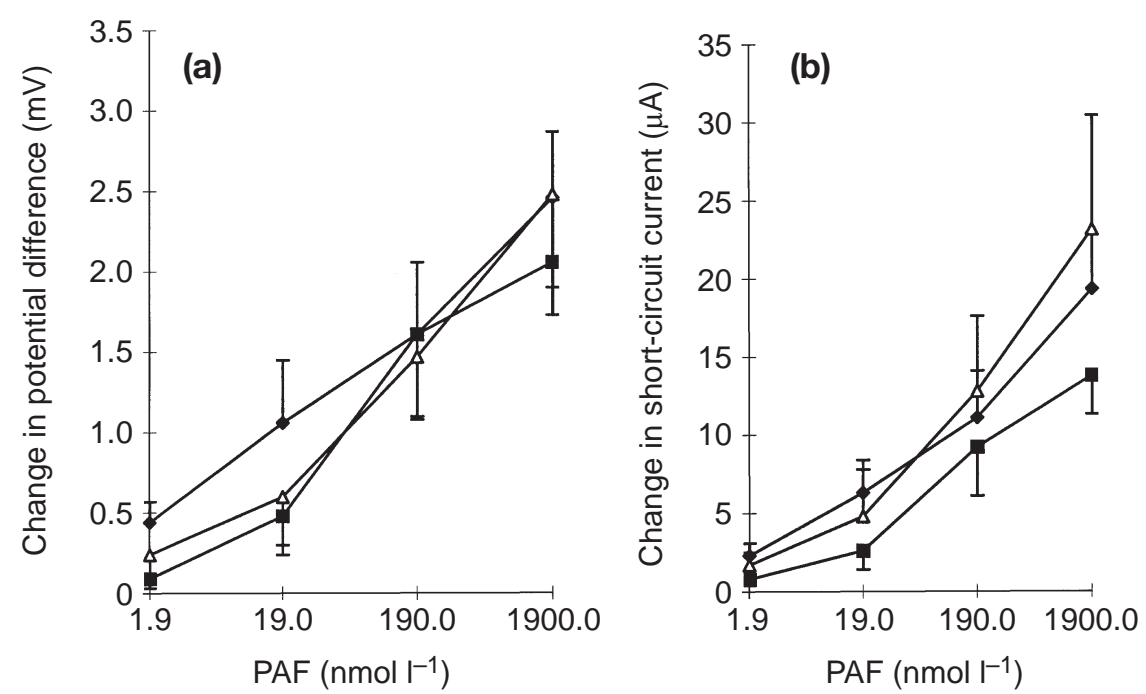

Fig. 3. (a) Change in potential difference and (b) change in short-circuit current with increasing concentration of platelet-activating factor (PAF) in cultured human Fallopian tubal epithelial cells in the absence $(\bullet, n=14)$ or presence of $2.5 \mu \mathrm{l}$ methanol ml-1 $(\square, n=10)$ or $2.5 \mu \mathrm{lDMSO} \mathrm{ml}^{-1}(\triangle, n=10)$. Values represent mean \pm SEM.

cells in a number of species (Stoddart et al., 1996; Velasquez et al., 1997, 2001; Lash and Legge, 2001). Expression of mRNA encoding the PAF receptor is restricted to the endosalpinx and is most prominent in the subepithelial cells located in the mucosal folds that protrude into the lumen of the oviduct. This finding is in accord with the observation that PAF has greater effects on transepithelial potential difference when applied to the apical surface of tubal epithelial cells rather than to the basal surface. PAF released by gametes or embryos could influence the functions of tubal epithelial cells by stimulating chloride ion movement across the tubal epithelium and thereby increasing the rate of production, or modulating the composition, of oviductal fluid. PAF increases glycoprotein secretion in tracheal (Larivee et al., 1994) and middle ear epithelial cells (Lin et al., 1995), and may have a similar action on tubal epithelial cells. In this way gametes and embryos may control their immediate environment. Hunter (1994) suggested that, by increasing the viscosity of luminal fluid, oviduct glycoproteins could stabilize the microenvironments that surround the gametes and embryo, thus preventing dispersal of nutrients and ions. We propose that signal molecules, secreted in small amounts by the embryo, have a restricted, local action on the ciliated cells and smooth muscle to propel the embryo towards the uterus. Increased ciliary beat of hamster oviduct ciliated epithelial cells has been observed after addition of physiological concentrations of PAF in vitro (Hermoso and Villalon, 1995); however, whether PAF acts by increasing contractile activity of the myosalpinx is not known. If embryoderived PAF acts on the myosalpinx, the endosalpinx may be acting as an intermediary in this embryo-maternal dialogue (Velasquez et al., 2001). How such a signal received by tubal epithelial cells would be relayed to the endometrium is unclear; however, PAF increases intracellular $\mathrm{Ca}^{2+}$ concentration in bovine oviduct epithelial cells by promoting influx of extracellular $\mathrm{Ca}^{2+}$ (Tiemann et al., 1996) and also increases arachidonic acid and prostaglandin production by epithelial cells (for a review, see Chao and Olson, 1993). Both processes could be a mechanism for amplifying signals from the developing embryo.

The present study has shown that PAF, which appears to act predominately at the apical surface of the tubal epithelial cell, influences transepithelial potential differences by modulating $\mathrm{Cl}^{-}$fluxes. Therefore, in humans, PAF may act as a signal from the gametes to the oviduct or the early embryo to the oviduct in vivo.

This work was supported by The Wellcome Trust. The authors would like to thank C. Hall and J. Hawkhead for technical assistance with cell cultures.

\section{References}

Alecozay AA, Casslen BG, Riehl RM, DeLeon FD, Harper MJK, Silva M, Nouchi TA and Hanahan DJ (1989) Platelet-activating factor (PAF) in human luteal phase endometrium Biology of Reproduction 41 578-586

Alecozay AA, Harper MJK, Schenken RS and Hanahan DJ (1991) Paracrine interactions between platelet-activating factor and prostaglandins in hormonally-treated human luteal phase endometrium in vitro. Journal of Reproduction and Fertility 91 301-312

Angle MJ, Jones MA, McManus LM, Pinckard RN and Harper MJK (1988) Platelet-activating factor in the rabbit uterus during early pregnancy Journal of Reproduction and Fertility 83 711-722

Bongso A, Ng SC, Fong CY, Anandakumar C, Marshall B, Edirisinghe R and Ratnam S (1992) Improved pregnancy rates after transfer of embryos grown in human Fallopian tubal co-culture Fertility and Sterility 58 569-574

Case RM, Lau KR, Steward M, Brown PD and Elliot AC (1989) Molecular mechanisms of transport: small and large molecules Biochemical Society Transactions $\mathbf{1 7} 803-805$

Chao W and Olson MS (1993) Platelet-activating factor: receptors and signal transduction Biochemical Journal 292 617-629 
Comer MT, Leese HJ and Southgate J (1998) Induction of a differentiated ciliated cell phenotype in primary cultures of Fallopian tube epithelium Human Reproduction 13 3114-3120

Deachapunya C and O'Grady SM (1998) Regulation of chloride secretion across porcine endometrial epithelial cells by prostaglandin $\mathrm{E}_{2}$ Journal of Physiology (London) 508 31-47

Dickens CJ and Leese HJ (1994) The regulation of rabbit oviduct fluid formation Journal of Reproduction and Fertility 100 577-581

Dickens CJ, Southgate J and Leese HJ (1993) Use of primary cultures of rabbit oviduct epithelial cells to study the ionic basis of tubal fluid formation Journal of Reproduction and Fertility 98 603-610

Dickens CJ, Comer MT, Southgate J and Leese HJ (1996) Human Fallopian tubal epithelial cells in vitro: establishment of polarity and potential role of intracellular calcium and extracellular ATP in fluid secretion Human Reproduction $11212-217$

Downing SJ, Maguiness SD, Watson A and Leese HJ (1997) Electrophysiological basis of human Fallopian tubal fluid formation Journal of Reproduction and Fertility 111 29-34

Downing SJ, Chambers EL, Maguiness SD, Watson A and Leese HJ (1999) Effect of inflammatory mediators on the electrophysiology of the human oviduct Biology of Reproduction 61 657-664

Dytham C (1999) The tests 1: test to look at differences. In Choosing and Using Statistics A Biologist's Guide pp 61-146 Blackwell Science Ltd, London, Edinburgh

Glasser SR, Julian J, Decker GL, Tang J-P and Carson DD (1988) Development of morphological and functional polarity in primary cultures of immature rat uterine epithelial cells Journal of Cell Biology 107 2409-2423

Gott AL, Gray SM, James AF and Leese HJ (1988) The mechanism and control of rabbit oviduct fluid formation Biology of Reproduction 39 758-763

Hanglow AC, Bienenstock J and Perdue MH (1989) Effects of plateletactivating factor on ion transport in isolated rat jejunum American Journal of Physiology 257 G845-G850

Hansel W, Stock A and Battista PJ (1989) Low molecular weight lipidsoluble luteotrophic factors produced by conceptuses in cows Journal of Reproduction and Fertility Supplement 37 11-17

Henriksen T, Tanbo T, Abyholm TH, Oppedal BR, Clausson OP and Hovig T (1990) Epithelial cells from human Fallopian tube in culture Human Reproduction 5 25-31

Hermoso MA and Villalon MJ (1995) Embryo-secreted factors increase the frequency of ciliary beat of hamster oviductal ciliated cells in vitro. Biology of Reproduction 52 S1-180

Hunter RHF (1994) Modulation of gamete and embryonic microenvironments by oviduct glycoproteins Molecular Reproduction and Development 39 176-181

Jin $\mathbf{W}$ and Hopfer $\mathbf{U}$ (1997) Purinergic-mediated inhibition of $\mathrm{Na}^{+}-\mathrm{K}^{+}-$ATPase in proximal tubule cells: elevated cytosolic $\mathrm{Ca}^{2+}$ is not required American Journal of Physiology 272 C1169-C1177

Kasamo M, Brandt M, Ishikawa M, Shimizu T and Harper MJK (1992) In vitro prostaglandin release from and platelet-activating factor accumulation in isolated endometrial cells from pregnant and pseudopregnant rabbits Biology of Reproduction 46 829-845

Kimber SJ, Waterhouse $\mathbf{R}$ and Lindenberg S (1993) In vitro models for implantation in the mammalian embryo. In Preimplantation Embryo Development, Serono Symposia USA pp 244-263 Ed. BD Bavister. Springer-Verlag, Amsterdam, New York

Larivee P, Levine SJ, Martinez A, Wu T, Logun C and Shelhammer JH (1994) Platelet-activating factor induces airway mucin release via activation of protein kinase $\mathrm{C}$ : evidence for translocation of protein kinase $\mathrm{C}$ to membranes American Journal of Respiratory Cell and Molecular Biology 11 199-205

Lash GE and Legge $\mathbf{M}$ (2001) Localization and distribution of platelet activating factor receptors in the mouse ovary and oviduct during the estrous cycle and early pregnancy American Journal of Reproduction and Immunology 45 123-127

Leese HJ, Tay JI, Reischl J and Downing SJ (2001) Formation of Fallopian tubal fluid: physiology of a neglected epithelium Reproduction 121 339-346
Lewis SA, Berg JR and Kleine TJ (1995) Modulation of epithelial permeability by extracellular macromolecules Physiological Reviews 75 561-589

Lin J, Kim Y, Lees C and Juhn SK (1995) Effect of platelet-activating factor on secretion of mucous glycoprotein from chinchilla middle ear epithelial cells in vitro. European Archives of Otorhinolaryngology 252 92-96

MacNaughton WK and Gall DG (1991) Mechanisms of platelet-activating factor-induced electrolyte transport in the rat jejunum European Journal of Pharmacology 200 17-23

Matsubara T, Yasuda K, Johnston JM, Sanezumi M, Okada H, Matsuoka S and Kanzaki H (1997) Platelet-activating factor (PAF) and PAF acetylhydrolase activity in rat uterus and placenta during the late stages of pregnancy Biology of Reproduction 56 885-890

Matthews CJ, Thomas EJ, Redfern CPF and Hirst BH (1993) lon transport by human endometrial epithelia in vitro. Human Reproduction $\mathbf{8}$ 1570-1575

Minhas B, Zhu Y-P, Kim H-N, Burwinkel TH, Ripps BA and Buster JE (1993) Embryonic platelet activating factor production in the rabbit increases during the preimplantation phase Journal of Assisted Reproduction and Genetics $10366-370$

O'Grady SM, Palfrey HC and Field M (1987) Characteristics and functions of $\mathrm{Na}-\mathrm{K}-\mathrm{Cl}$ co-transport in epithelial tissues American Journal of Physiology 253 C177-C192

O'Neill C (1985) Partial characterization of the embryo-derived plateletactivating factor in mice Journal of Reproduction and Fertility 75 375-380

Ortiz ME, Bedregal P, Carvajal MI and Croxatto HB (1986) Fertilized and unfertilized ova are transported at different rates by hamster oviduct Biology of Reproduction 34 777-781

Quinton PM (1990) Cystic fibrosis: a disease in electrolyte transport FASEB Journal 4 2709-2717

Reischl J, Downing SJ and Leese HJ (1999) Electrophysiological studies on bovine oviduct epithelial cells in primary culture Journal of Reproduction and Fertility Abstract Series 2324

Reischl J, Downing SJ and Leese HJ (2000) lon transport in bovine oviduct epithelial cells Theriogenology 5347

Roudebush WE and Purnell ET (2000) Platelet-activating factor content in human spermatozoa and pregnancy outcome Fertility and Sterility $\mathbf{7 4}$ 257-260

Stoddart NR, Wild AE and Fleming TP (1996) Stimulation of development in vitro by platelet activating factor receptor ligands released by mouse preimplantation embryos Journal of Reproduction and Fertility $\mathbf{1 0 8}$ 47-53

Tiemann U, Neels P, Kuchenmeister U, Weels H and Spitschak M (1996) Effect of ATP and platelet-activating factor on intracellular calcium concentrations of cultured oviductal cells from cows Journal of Reproduction and Fertility 108 1-9

Velasquez L, Aguilera JG and Croxatto HB (1995) Possible role of plateletactivating factor (PAF) in embryonic signalling during oviductal transport in the hamster Biology of Reproduction 52 1302-1306

Velasquez LA, Ojeda SR and Croxatto CB (1997) Expression of plateletactivating factor receptor in the hamster oviduct: localization to the endosalpinx Journal of Reproduction and Fertility 109 349-354

Velasquez LA, Maisey K, Fernandez R, Valdes D, Cardenas H, Imrai M, Delgado J, Aguilera J and Croxatto HB (2001) PAF receptor and PAF acetylhydrolase expression in the endosalpinx of the human Fallopian tube: possible role of embryo-derived PAF in the control of embryo transport to the uterus Human Reproduction 16 1583-1587

Zeitlin PL, Wagner M, Markakis D, Loughlin GM and Guggino WB (1989) Steroid hormones: modulators of $\mathrm{Na}^{+}$absorption and $\mathrm{Cl}^{-}$secretion in cultured tracheal epithelia Proceedings National Academy of Sciences USA 86 2502-2505

Received 5 March 2002.

First decision 10 April 2002.

Revised manuscript received 10 May 2002.

Accepted 26 June 2002. 